\title{
Prising av forskning
}

Vår hverdag er preget av vitenskap og teknologi. Og etter hvert som samfunnets kompleksitet øker, vil avhengigheten av kunnskap frembrakt av forskere øke tilsvarende. Forskning er derfor å se på som en vesentlig samfunnsressurs og bør styres til fellesskapets beste. Ikke all forskning er like verdifull, og for å lette den administrative fordeling av begrensede statlige virkemidler har det vært ansett som nødvendig å finne et troverdig mål på forskningskvalitet. Et slikt kvalitetsmål har man nå fått ved at de fleste vitenskapelige publikasjonskanaler er blitt tilordnet plass i et kvalitetshierarki (1). Ved å koble forfatternes institusjonstilhørighet til publikasjonskanalens verdi kan man relativt enkelt kreditere riktig mengde forskningsmidler til rett adresse. Ved dette grepet vil forskeren gjennom sin institusjon få betalt for innsatsen og samfunnet kan høste gevinst ved at kun de beste prosjekter blir finansiert.

Logikken bak argumentasjonen for resultatbasert finansiering er såre enkel, og gitt de førende politisk-økonomiske premisser tvinges finansieringsordningen frem som en ugjendrivelig konklusjon. Ordningen er transparent, enkel å administrere og institusjonalisert gjennom fagråd ved landets universiteter og helseforetak. Likevel finnes det en og annen kritisk røst som ikke avfinner seg med premissene for verdifastsetting og derfor heller ikke kan akseptere konklusjonen.

I økonomiens verden er «verdi» en størrelse som fastsettes i markedet, og produktets innpakning er i så måte overordnet kvalitativt innhold. I forskningens verden er forholdet motsatt - der er kvalitativt innhold overordnet innpakningen. Denne ulikheten utviskes ved innføring av resultatbasert forskningsfinansiering: Det fremtvinges et økonomisk syn på forskningens «produkt», og forskerne drives inn i markedsdomenet. Men siden «produktet» ikke kan omsettes fritt $i$ et marked, har det vært ansett som nødvendig å finne andre kriterier for prising. Det naturlige valget - å lese gjennom en publikasjon for å vurdere dens verdi - er en kompetanse- og kostnadskrevende aktivitet og i byråkratisk sammenheng derfor uhensiktsmessig. For å gjøre det hele enkelt og brukervennlig er det i stedet innført et pseudomål på kvalitet: Publikasjonskanalens plassering $i$ et kvalitetshierarki. Ved dette grepet har man ikke lenger bruk for forskerkompetanse når kvalitet skal vurderes, og ressurser spares ved at belønningsmidler kan fordeles administrativt. Gjennom ordningen får forskerne verdifull tid ved at de får konsentrert seg om det de skal og ønsker - drive forskning. Og overfladisk sett kan det se ut til at den økonomiske tenkningen har vært funksjonell forskerne publiserer mer for hver investerte krone.

Men dette betyr ikke nødvendigvis at kvaliteten på forskningen $ø$ ker tilsvarende. Forskere kan ikke drive vitenskap uten penger og er derfor avhengige av å få publisert sine resultater. Siden forskningsmidler med dagens system tilflyter forskerne i forhold til antall «kvalitetssikrede» publikasjoner, vil de med nødvendighet måtte konsentrere seg om oppgaver som er gjennomførbare innenfor korte tidsintervaller. Hovedvekten blir dermed lagt på løsbare oppgaver, ikke på oppgaver som må løses. Til en viss grad kan misforholdet rettes opp ved at må-oppgaver blir prioritert. Men hvem skal i tilfelle identifisere oppgavene og prioritere tiltak? Og hvem skal anses som ekspert dersom problemstillingen er av en slik natur at den krever tverrvitenskapelig kompetanse?
$\AA$ vurdere et arbeids vitenskapelige verdi er faglig krevende, men kan hende er det en kostnad samfunnet bør ta. Å konstruere måltall for forskingsverdi basert på en kategorisering er uansett ikke veien å gå. Ved all kategorisering vil det fremkomme en abstrakt og komprimert viten der omkostningene er tap av informasjon. Og dersom den tapte informasjonen er betydningsfull, risikerer man å fordele forskningsmidler på feil premisser. Da er vi inne i det som tidligere er blitt omtalt som den instrumentelle feiltakelsen - en ureflektert og ideologipreget handling som utføres som følge av anvendelse av uegnet måleverktøy (2). Til grunn for denne feiltakelsen ligger troen på at komplekse fenomener kan fastslås entydig ved hjelp av dårlig kalibrerte måleinstrumenter. Kategorisering av kvalitet basert på en grense bestemt ved « $20 \%$ av alt som publiseres innen dette fagfeltet» (1) vil kunne falle inn under denne feiltakelsen. For dersom denne verdien er tilfeldig satt, hvordan kan måleinstrumentet da levere resultater som er tillitvekkende? Et minimumskrav ved måling av kvalitet er jo at måleinstrumentet selv har dokumenterbar kvalitet.

Dersom ikke forskersamfunnet forholder seg kritisk til premissene forskningsmidlene styres etter, risikerer man at kategoriene fremtrer som objektive referanser på kvalitet. Vi får da den paradoksale situasjonen at et praktisk virkemiddel, verdibasert kategorisering, blir objektiv sannhet. Konsekvensen kan bli at dyktige forskere blir nedvurdert og dårligere forskere oppvurdert. En annen konsekvens kan bli at forskningen drives enda sterkere i retning av resultatproduksjon. Dette vil være en svært uheldig dreining fordi forståelsen av komplekse medisinske fenomener likeså mye som dataproduksjon krever kunnskapsproduksjon. «La data tale for seg selv,» var oppfordringen jeg fikk da jeg som stipendiat presenterte noen forvirrende, men metodisk korrekt frembrakte data. Men ingen tror vel lenger i fullt alvor at data taler for seg selv?

Målstyring av aktivitet er velegnet i visse industrielle sammenhenger, men neppe like egnet for kunnskapsbedrifter. Faren ved resultatbasert finansiering i slike institusjoner er at målstyringen på lengre sikt kan resultere i målforskyvning, ved at byråkratiske løsninger erstatter faglige vurderinger ved valg av forskningsspørsmål. Dersom de involverte aktører endrer praksis for å tilpasse seg byråkratiske forordninger, blir resultatet en meningsløs, men likevel rasjonell aktivitet. Det hele blir et strategisk spill der de forskerne som fortest klarer å snu kappen etter vinden vinner frem. Taperen på lengre sikt blir samfunnet og pasientene det produserer.

\section{Elling Ulvestad}

elling.ulvestad@helse-bergen.no

Elling Ulvestad (f. 1958) er avdelingsoverlege og professor ved Avdeling for mikrobiologi og immunologi, Haukeland universitetssykehus, og Gades Institutt, Universitetet i Bergen. Han er redaktør for Acta Pathologica, Microbiologica et Immunologica Scandinavica og redaksjonsmedlem i Naturen.

Oppgitte interessekonflikter: Ingen

\section{Litteratur}

1. Johannessen A, Gilhus NE. Resultatbasert finansiering av medisinsk forskning Tidsskr Nor Legeforen 2009; 129: 638-41.

2. Ulvestad E. Det instrumentelle dilemma. Nytt Norsk Tidsskrift 2006; nr. 3 : 229-40. 